\title{
The Role of Hydrogen Sulfide in Renal System
}

\author{
Xu Cao and Jin-Song Bian* \\ Department of Pharmacology, Yong Loo Lin School of Medicine, National University of Singapore, Singapore, Singapore
}

Hydrogen sulfide has gained recognition as the third gaseous signaling molecule after nitric oxide and carbon monoxide. This review surveys the emerging role of $\mathrm{H}_{2} \mathrm{~S}$ in mammalian renal system, with emphasis on both renal physiology and diseases. $\mathrm{H}_{2} \mathrm{~S}$ is produced redundantly by four pathways in kidney, indicating the abundance of this gaseous molecule in the organ. In physiological conditions, $\mathrm{H}_{2} \mathrm{~S}$ was found to regulate the excretory function of the kidney possibly by the inhibitory effect on sodium transporters on renal tubular cells. Likewise, it also influences the release of renin from juxtaglomerular cells and thereby modulates blood pressure. A possible role of $\mathrm{H}_{2} \mathrm{~S}$ as an oxygen sensor has also been discussed, especially at renal medulla. Alternation of $\mathrm{H}_{2} \mathrm{~S}$ level has been implicated in various pathological conditions such as renal ischemia/reperfusion, obstructive nephropathy, diabetic nephropathy, and hypertensive nephropathy. Moreover, $\mathrm{H}_{2} \mathrm{~S}$ donors exhibit broad beneficial effects in renal diseases although a few conflicts need to be resolved. Further research reveals that multiple mechanisms are underlying the protective effects of $\mathrm{H}_{2} \mathrm{~S}$, including anti-inflammation, anti-oxidation, and anti-apoptosis. In the review, several research directions are also

OPEN ACCESS

Edited by: Giovanni Li Volti, University of Catania, Italy

Reviewed by: Christos Argyropoulos, University of New Mexico, USA Valentina Vellecco, University of Naples Federico II, Italy

*Correspondence: Jin-Song Bian phcbjs@nus.edu.sg

Specialty section:

This article was submitted to Experimental Pharmacology and Drug

Discovery,

a section of the journal

Frontiers in Pharmacology

Received: 17 August 2016 Accepted: 03 October 2016 Published: 18 October 2016

Citation: Cao X and Bian J-S (2016) The Role of Hydrogen Sulfide in Renal System.

Front. Pharmacol. 7:385. doi: 10.3389/fphar.2016.00385 proposed including the role of mitochondrial $\mathrm{H}_{2} \mathrm{~S}$ in renal diseases, $\mathrm{H}_{2} \mathrm{~S}$ delivery to kidney by targeting D-amino acid oxidase/3-mercaptopyruvate sulfurtransferase (DAO/3-MST) pathway, effect of drug-like $\mathrm{H}_{2} \mathrm{~S}$ donors in kidney diseases and understanding the molecular mechanism of $\mathrm{H}_{2} \mathrm{~S}$. The completion of the studies in these directions will not only improves our understanding of renal $\mathrm{H}_{2} \mathrm{~S}$ functions but may also be critical to translate $\mathrm{H}_{2} \mathrm{~S}$ to be a new therapy for renal diseases.

Keywords: hydrogen sulfide, $\mathrm{H}_{2} \mathrm{~S}$, renal physiology, acute kidney injury, chronic kidney disease, diabetic nephropathy

\section{INTRODUCTION}

Hydrogen sulfide has been regarded as a toxic gas for 100s of years (Smith and Gosselin, 1979). It can directly inhibit the activity of several essential enzymes in human namely cytochrome $\mathrm{c}$ oxidase (Reiffenstein et al., 1992), carbonic anhydrase (Nicholson et al., 1998), monoamine oxidase (Warenycia et al., 1989), and $\mathrm{Na}^{+} / \mathrm{K}^{+}$ATPase (Reiffenstein et al., 1992), thereby causing toxicity.

Abbreviations: AC, adenylate cyclase; AMPK, 5' AMP-activated protein kinase; AOAA, aminooxyacetic acid; CaMTg, pancreatic $\beta$-cell specific calmodulin-overexpressing transgenic; CAT, cysteine aminotransferase; CBS, cystathionine $\beta$-synthase; CKD, chronic kidney disease; CO, carbon monoxide; CSE, cystathionine $\gamma$-lyase; DAO, D-amino acid oxidase; $\mathrm{DN}$, diabetic nephropathy; EDHF, endothelium-derived hyperpolarizing factor; EDRF, endothelium-derived relaxing factor; GFR, glomerular filtration rate; $\mathrm{H}_{2} \mathrm{~S}$, hydrogen sulfide; IRI, ischemia/reperfusion injury; JG, juxtaglomerular; MAPK, mitogen-activated protein kinase; MMP-9, matrix metalloproteinase-9; NF- $\mathrm{B}$, nuclear factor- $\kappa \mathrm{B}$; NKA, $\mathrm{Na}^{+} / \mathrm{K}^{+}$ATPase; NKCC, $\mathrm{Na}^{+} / \mathrm{K}^{+} / 2 \mathrm{Cl}^{-}$cotransporter; NO, nitric oxide; PAG, DL-propargylglycine; RAS, renin-angiotensin system; ROS, reactive oxygen species; STZ, streptozotocin; Uk.V, urinary potassium; UNa.V, urinary sodium; VEGF, vascular endothelial growth factor; 3-MP, 3-mercaptopyruvate; 3-MST, 3-mercaptopyruvate sulfurtransferase. 
However, the image of $\mathrm{H}_{2} \mathrm{~S}$ has been largely expanded since the revelation of $\mathrm{H}_{2} \mathrm{~S}$ as an endogenous neuronal modulator by Kimura's group in Abe and Kimura (1996). Thereafter, the physiological significance of $\mathrm{H}_{2} \mathrm{~S}$ has been extensively studied especially in central nervous system (Zhang and Bian, 2014) and cardiovascular system (Liu et al., 2012). Emerging evidence has suggested that $\mathrm{H}_{2} \mathrm{~S}$ also actively regulates renal function and is implicated in numerous kidney diseases in recent years. Here in this review, recent studies regarded the role of $\mathrm{H}_{2} \mathrm{~S}$ in both kidney physiology and diseases will be discussed.

\section{PHYSICAL AND CHEMICAL PROPERTIES OF $\mathrm{H}_{2} \mathrm{~S}$}

Hydrogen sulfide exists as a colorless gas with a strong rotten egg smell at room temperature and ambient pressure. The human nose can detect a concentration of 400-fold lower than its toxic level (Wang, 2002), whereas, long term exposure can cause desensitization of olfactory nerves to $\mathrm{H}_{2} \mathrm{~S}$ (Li et al., 2009). Distinct from the other gaseous transmitters like $\mathrm{NO}$ and $\mathrm{CO}, \mathrm{H}_{2} \mathrm{~S}$ is a weak acid and hence able to readily dissolve in water. Based on its $\mathrm{PKa}$, it is estimated that there will be $14 \% \mathrm{H}_{2} \mathrm{~S}$ gas, $86 \% \mathrm{HS}^{-}$ and a trace of $\mathrm{S}^{2-}$ in physiological condition $\left(\mathrm{pH} 7.4,37^{\circ} \mathrm{C}\right.$; $\mathrm{Li}$ et al., 2009). Moreover, $\mathrm{H}_{2} \mathrm{~S}$ gas is highly lipophilic which allows it freely to penetrate into the cell membrane of all types and become biologically active (Mathai et al., 2009).

\section{$\mathrm{H}_{2}$ S GENERATION IN THE KIDNEY}

Three traditional $\mathrm{H}_{2} \mathrm{~S}$ synthesizing pathways have been identified in mammalians including CSE (EC 4.4.1.1), CBS (EC 4.2.1.22), and 3-MST (EC 2.8.1.2) coupled with CAT (EC 2.6.1.3) pathways. The mechanisms underlying these traditional pathways can be found in our previous review in detail (Liu et al., 2012). In short, CSE firstly dimerizes two L-cysteine to L-cystine followed by transforming it into pyruvate, $\mathrm{NH}_{3}$ and thiocysteine. The resulted thiocystein is then used as a substrate by CSE to react with other thiols to generate $\mathrm{H}_{2} \mathrm{~S}$ (Stipanuk and King, 1982). CBS catalyzes the reaction between L-cysteine and homocystenin into cystathinine and $\mathrm{H}_{2} \mathrm{~S}$ (Szabo, 2007). However, 3-MST is unable to directly use L-cysteine as a substrate as its counterpart does. $\mathrm{L}$-cysteine has to be transformed into 3-MP by CAT which is then catalyzed by 3-MST into pyruvate and $\mathrm{H}_{2} \mathrm{~S}$ (Shibuya et al., 2009). It is worth mentioning that both CSE and CBS require pyridoxal 5'-phosphate as a cofactor to synthesize $\mathrm{H}_{2} \mathrm{~S}$, while 3-MST is dependent on zinc (Li et al., 2009). In addition, CSE and CBS mainly locate in cytosol yet they can translocate into mitochondria in some oxidative conditions (Fu et al., 2012), whereas 3-MST resides and generates $\mathrm{H}_{2} \mathrm{~S}$ in mitochondria (Kimura, 2011).

A fourth $\mathrm{H}_{2} \mathrm{~S}$ generation pathway namely DAO/3-MST pathway was discovered recently by Kimura's group (Shibuya et al., 2013). In the study, they showed that kidney lysate can produce 60 times more $\mathrm{H}_{2} \mathrm{~S}$ when using D-cysteine as substrate comparing with L-cysteine. Further, the underlying mechanism was studied. Specifically, D-cysteine is transformed into 3-MP by peroxisome located DAO. Due to metabolite exchanges between peroxisome and mitochondria, 3-MP is imported into mitochondria and catalyzed into $\mathrm{H}_{2} \mathrm{~S}$ by $3-\mathrm{MST}$. Since DAO is only located in brain and kidney, this $\mathrm{H}_{2} \mathrm{~S}$ generating pathway is believed to exclusively exist in brain and kidney.

Hydrogen sulfide generation is abundant in kidney given the presence of all the above mentioned pathways in this organ (Figure 1). Currently, it is believed that CSE and CBS are the dominated enzymes for $\mathrm{H}_{2} \mathrm{~S}$ generation in kidney. The presence of these two enzymes was firstly demonstrated in 1980s by using their inhibitors (Stipanuk and Beck, 1982). Later on, House et al. (1997) suggested that both enzymes were mainly located on renal proximal tubules within the renal cortex by comparison with marker enzymes of known location. This finding was supported by several other studies using different methods (Ishii et al., 2004; Li et al., 2006; Tripatara et al., 2009). However, inconsistent results have been reported regarding the existence of these two enzymes in glomerulus which needs to be resolved (Aminzadeh and Vaziri, 2012; Bos et al., 2013; Yamamoto et al., 2013). In addition, definitive evidence has suggested the presence of 3-MST in kidney (Aminzadeh and Vaziri, 2012; Shibuya et al., 2013; Kimura, 2014; Pan et al., 2015), however, the significance of 3-MST mediated $\mathrm{H}_{2} \mathrm{~S}$ generating pathway has not been well-acknowledged in both kidney physiology and diseases due to limited reports. Nevertheless, the revelation of the unique DAO/3-MST pathway in kidney and brain may imply a significant role of 3-MST mediated $\mathrm{H}_{2} \mathrm{~S}$ generation in these organs. This will be an interesting area open to explore in the next years.

\section{EFFECT OF $\mathrm{H}_{2}$ S ON RENAL PHYSIOLOGY}

\section{$\mathrm{H}_{2} \mathrm{~S}$ Effect on Renal Excretory Function}

The necessity of $\mathrm{H}_{2} \mathrm{~S}$ producing enzymes have long been recognized in the kidney due to their critical effect on homocysteine metabolism (Stipanuk, 2004), however, the effect of $\mathrm{H}_{2} \mathrm{~S}$ itself on renal function was not studied until recently. Intra-renal infusion of $\mathrm{H}_{2} \mathrm{~S}$ donor $\mathrm{NaHS}$ is able to increase GFR, $\mathrm{UNa} \cdot \mathrm{V}$ and potassium (Uk.V) excretion (Xia et al., 2009; Ge et al., 2014). Moreover, the effect is closely mimicked by the infusion of L-cysteine, an $\mathrm{H}_{2} \mathrm{~S}$ generating substrate (Xia et al., 2009). In addition, inhibition of endogenous $\mathrm{H}_{2} \mathrm{~S}$ production by AOAA (CBS inhibitor) plus PAG (CSE inhibitor) leads to the decrease of GFR, UNa.V and Uk.V, suggesting that $\mathrm{H}_{2} \mathrm{~S}$ regulates renal function in physiological conditions. However, either AOAA or PAG alone fails to produce any effect on renal function implicating a compensatory effect between CBS and CSE on renal regulation which has been confirmed by another study (Roy et al., 2012). Hypothesis concerning the effects of $\mathrm{H}_{2} \mathrm{~S}$ on sodium transporters was formed and tested thereafter. The results showed that $\mathrm{H}_{2} \mathrm{~S}$ significantly inhibited the activity of NKCC and NKA which may account for its effect on renal function (Figure 2A). Recently, the mechanism of the inhibitory effect of $\mathrm{H}_{2} \mathrm{~S}$ on NKA was studied by Zhu's group (Ge et al., 2014). In 


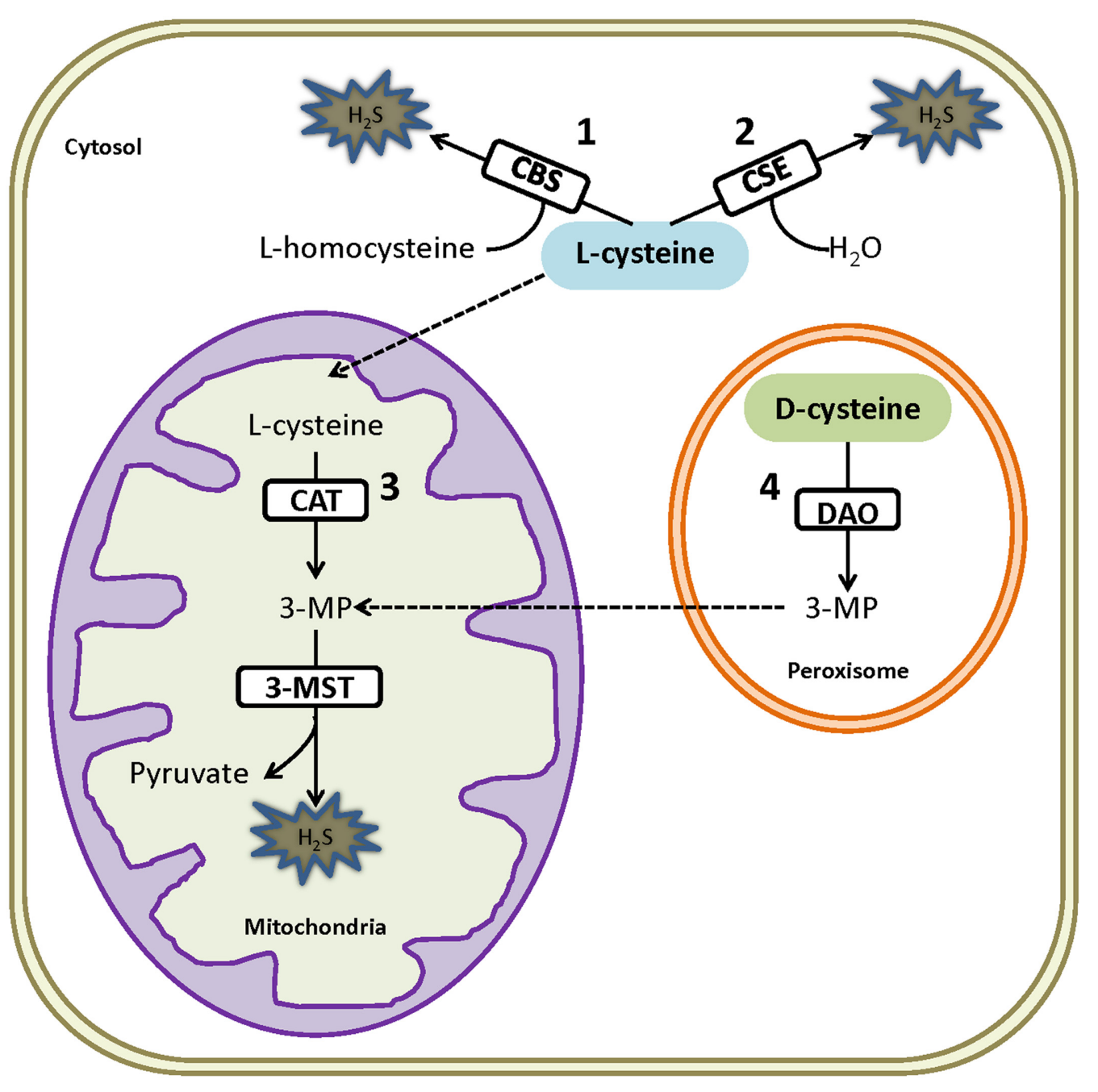

FIGURE 1 | Endogenous synthesis of $\mathbf{H}_{2} \mathbf{S}$ by four pathways in renal system. (1) $\mathrm{CBS}$ mediated $\mathrm{H}_{2} \mathrm{~S}$ synthesis by using L-cysteine as the substrate in cytosol; (2) CSE mediated $\mathrm{H}_{2} \mathrm{~S}$ synthesis with L-cysteine as the substrate in cytosol; (3) CAT transforms L-cysteine into 3MP which is further catalyzed by 3-MST into $\mathrm{H}_{2} \mathrm{~S}$ in mitochondria; (4) Peroxisome resident DAO catalyzes D-cysteine into 3MP which is then exchanged into mitochondria and utilized by 3-MST for the production of $\mathrm{H}_{2} \mathrm{~S}$ in mitochondria. CBS, cystathionine $\beta$-synthase; CSE, cystathionine $\gamma$-lyase; 3-MST, 3-mercaptopyruvate sulfurtransferase; CAT, cysteine aminotransferase; DAO, D-amino acid oxidase; 3MP, 3-mercaptopyruvate.

their study, they showed that NaHS promoted NKA endocytosis by directly activating epidermal growth factor receptor (EGFR) in renal tubular epithelia cells. Moreover, EGFR cys797 mutation fully abolished the effect of $\mathrm{H}_{2} \mathrm{~S}$ suggesting a direct interaction between $\mathrm{H}_{2} \mathrm{~S}$ and this cysteine residue. Taken together, both endogenous and exogenous $\mathrm{H}_{2} \mathrm{~S}$ are able to increase GFR, UNa.V, and Uk.V excretion probably through the inhibitory effect on sodium transporters like NKCC and NKA.

Hydrogen sulfide increases $\mathrm{Cl}^{-} / \mathrm{HCO}_{3}{ }^{-}$exchanger activity in various tissues like aortic tissues (Liu and Bian, 2010) and vascular smooth muscle cells (Lee et al., 2007). However, the effect of $\mathrm{H}_{2} \mathrm{~S}$ on the exchanger in kidney is still unknown. It is likely that $\mathrm{H}_{2} \mathrm{~S}$ can also enhance the activity of $\mathrm{Cl}^{-} / \mathrm{HCO}_{3}{ }^{-}$exchanger in renal system. Considering the critical role of $\mathrm{Cl}^{-} / \mathrm{HCO}_{3}{ }^{-}$ exchanger in regulating the excretion of ions and homeostatic maintenance of physiological $\mathrm{pH}$, it will be of great value to reveal the effect of $\mathrm{H}_{2} \mathrm{~S}$ on $\mathrm{Cl}^{-} / \mathrm{HCO}_{3}{ }^{-}$exchanger activity and the subsequent consequence in kidney.

\section{$\mathrm{H}_{2} \mathrm{~S}$ Effect on Renin Release}

The RAS is a renovascular hormone system involved in the regulation of plasma sodium concentration and blood pressure (BP). Renin release from JG cells determines RAS activity and the process is known to be regulated by intracellular cAMP (Peters et al., 1993; Gambaryan et al., 1998; Schweda et al., 2007). Moreover, $\mathrm{H}_{2} \mathrm{~S}$ was reported to downregulate cAMP level in several cell types (Lim et al., 2008; Yong et al., 2008), implying that $\mathrm{H}_{2} \mathrm{~S}$ may modulate renin release. This was demonstrated by our group in $\mathrm{Lu}$ et al. (2010). It was found that NaHS inhibited the upregulation of renin mRNA and protein level in a model of renovascular hypertension accompanying with a reduction of intracellular cAMP level. 

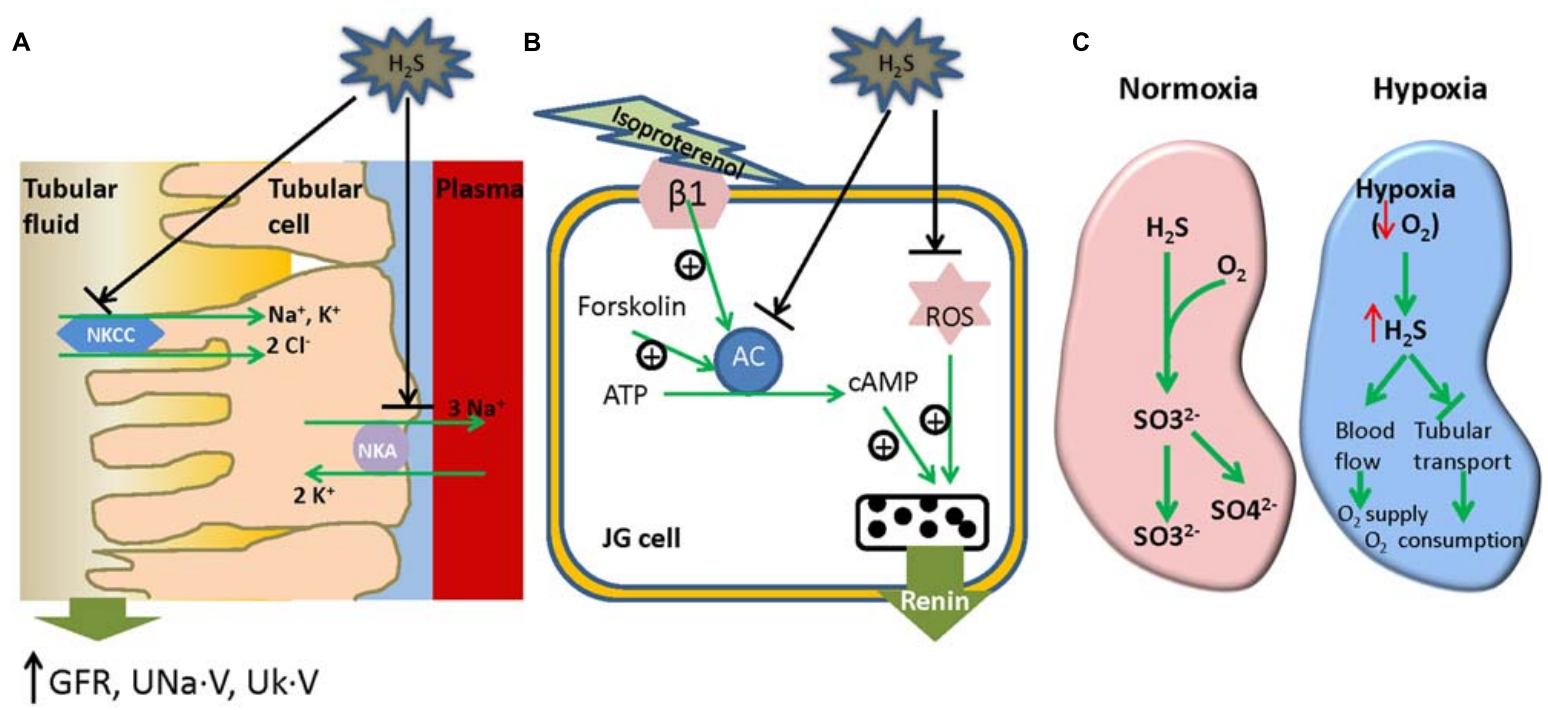

FIGURE 2 | Effects of $\mathbf{H}_{\mathbf{2}} \mathbf{S}$ on renal regulation. (A) $\mathrm{H}_{2} \mathrm{~S}$ inhibits the activity of tubular NKCC and NKA, thereby enhancing renal excretory function such as GFR, UNa.V and Uk.V. (B) $\mathrm{H}_{2} \mathrm{~S}$ suppresses renin release by inhibition of AC activity and ROS production in $\mathrm{GC}$ cells. (C) $\mathrm{H}_{2} \mathrm{~S}$ as an $\mathrm{O}_{2}$ sensor in the kidney. In normoxic condition, $\mathrm{H}_{2} \mathrm{~S}$ is metabolized into sulfates in the presence of $\mathrm{O}_{2}$; in hypoxic condition, the shortage of $\mathrm{O}_{2}$ leads to the accumulation of $\mathrm{H}_{2} \mathrm{~S}$ which helps to restore $\mathrm{O}_{2}$ level by enhancing blood flow and suppressing tubular transport activity in kidney. NKCC, $\mathrm{Na}^{+} / \mathrm{K}^{+} / 2 \mathrm{Cl}^{-} \mathrm{cotransporter}$ NKA, Na+/ $\mathrm{K}^{+} \mathrm{ATPase}$; GFR, glomerular filtration rate; UNa.V, urinary sodium; Uk.V, urinary potassium; $\beta 1, \beta 1$-adrenoceptor; ROS, reactive oxygen species; ATP, adenosine triphosphate; cAMP, cyclic adenosine monophosphate; JG cell, juxtaglomerular cell.

This is supported by another study (Lu et al., 2012) showing that $\mathrm{H}_{2} \mathrm{~S}$ regulates renin degranulation in As4.1 and rat reninrich kidney cells stimulated by isoproterenol, forskolin or 3isobutyl-1-methylxanthine. Further study demonstrated that $\mathrm{H}_{2} \mathrm{~S}$ significantly suppressed the stimulated AC activity in these cells. Overexpression of CSE also attenuates isoproterenol-induced renin release suggesting that endogenous $\mathrm{H}_{2} \mathrm{~S}$ may also involve in the process. However, the mechanism underlying the inhibitory effect of $\mathrm{H}_{2} \mathrm{~S}$ on $\mathrm{AC}$ remains to be determined, such as the identification of $\mathrm{AC}$ isoform(s) accounting for $\mathrm{H}_{2} \mathrm{~S}$ effect and the molecular interaction between $\mathrm{H}_{2} \mathrm{~S}$ and the $\mathrm{AC}$ isoform(s). Besides AC, ROS was recently reported to be a target of $\mathrm{H}_{2} \mathrm{~S}$ for its effect on renin reduction in DN suggesting participation of multiple mechanisms in the process (Xue et al., 2013). The effect of $\mathrm{H}_{2} \mathrm{~S}$ on renin activity in normal rats has also been investigated ( $\mathrm{Lu}$ et al., 2010). The results showed that neither NaHS administration nor inhibition of endogenous $\mathrm{H}_{2} \mathrm{~S}$ influenced renin activity implying that $\mathrm{H}_{2} \mathrm{~S}$ may only modulate renal activity when RAS is overactivated. The effect of $\mathrm{H}_{2} \mathrm{~S}$ on renin activity has been illustrated in Figure 2B.

\section{$\mathrm{H}_{2} \mathrm{~S}$ as an $\mathrm{O}_{2}$ Sensor in the Kidney}

Essentially all $\mathrm{H}_{2} \mathrm{~S}$ generation is independent of $\mathrm{O}_{2}$; however, the metabolism of $\mathrm{H}_{2} \mathrm{~S}$ is a process highly relying on $\mathrm{O}_{2}$ (Olson, 2015). Accumulating evidence suggests that $\mathrm{H}_{2} \mathrm{~S}$ is an $\mathrm{O}_{2}$ sensor in kidney, especially in medulla (Figure 2C). The availability of $\mathrm{O}_{2}$ in renal medulla is lower compared with that in renal cortex resulting in a higher abundance of $\mathrm{H}_{2} \mathrm{~S}$ in this region (Koning et al., 2015). Provided mitochondria can use $\mathrm{H}_{2} \mathrm{~S}$ as an electron donor for ATP production (Fu et al., 2012; Teng et al., 2013), it will be interesting to hypothesize that $\mathrm{H}_{2} \mathrm{~S}$ might be a direct source of energy in renal medulla. During hypoxia, $\mathrm{O}_{2}$ reduction leads to further accumulation of $\mathrm{H}_{2} \mathrm{~S}$ which help to recover $\mathrm{O}_{2}$ supply by increasing medullary blood flow and inhibition of tubular transport (Beltowski, 2010). In addition, CBS and CSE can translocate into mitochondria and stimulate $\mathrm{H}_{2} \mathrm{~S}$ production under hypoxic circumstances (Fu et al., 2012; Teng et al., 2013). The mitochondria derived $\mathrm{H}_{2} \mathrm{~S}$ may directly participate in ATP production. Currently, emerging physiological evidence for $\mathrm{H}_{2} \mathrm{~S}$ mediated $\mathrm{O}_{2}$ sensing has also been suggested in various $\mathrm{O}_{2}$ sensing tissues including cardiovascular system (Olson et al., 2006; Olson and Whitfield, 2010), respiratory system (Hu et al., 2008), gastrointestinal tract (Dombkowski et al., 2011) et al. However, the downstream effectors of $\mathrm{H}_{2} \mathrm{~S}$ mediated $\mathrm{O}_{2}$ sensing remains to be determined.

\section{$\mathrm{H}_{2} \mathrm{~S}$ IN ACUTE KIDNEY INJURY}

Acute kidney injury (formerly known as acute renal failure) is defined as a syndrome characterized by rapid loss of the kidney's excretory function. It is the clinical manifestation of several disorders that affect the kidney acutely (Bellomo et al., 2012). Here, $\mathrm{H}_{2} \mathrm{~S}$ effects in three types of acute kidney injury will be discussed namely renal IRI, obstructive nephropathy, and cisplatin nephrotoxicity.

\section{$\mathrm{H}_{2} \mathrm{~S}$ in Renal Ischemia/Reperfusion Injury}

Renal IRI is a major cause of acute kidney injury. The pathophysiological mechanism underlying renal IRI is very 
complex containing ATP depletion, calcium overload, ROS generation, apoptotic and inflammatory responses et al (Eltzschig and Eckle, 2011). The engagement of endogenous $\mathrm{H}_{2} \mathrm{~S}$ in renal IRI has been thoroughly demonstrated in various studies. Specifically, both mRNA and protein levels of CSE and CBS are apparently reduced upon IRI along with the reduction of $\mathrm{H}_{2} \mathrm{~S}$ level in kidney and plasma (Xu et al., 2009; Han et al., 2015), although mechanisms underlying IRI caused CSE and CBS reduction are still not revealed. In addition, inhibition of either CSE or CBS by their pharmacological inhibitors severely aggravates renal damage (Tripatara et al., 2008; Han et al., 2015) indicating that the ischemic renal injury might, at least in part, results from the impaired endogenous production of $\mathrm{H}_{2} \mathrm{~S}$. The implication is supported by a recent finding that CSE-deficiency associates with increased renal damage and mortality after renal IRI which might be due to the enhanced production of ROS (Bos et al., 2013). Subsequently, the effect of exogenous $\mathrm{H}_{2} \mathrm{~S}$ was extensively studied in various renal IRI scenarios (Tripatara et al., 2008, 2009; Bos et al., 2009, 2013; Xu et al., 2009; Simon et al., 2011; Hunter et al., 2012; Zhu et al., 2012; Azizi et al., 2015; Han et al., 2015; Ahmad et al., 2016) which have been summarized in Table 1. In most studies, an $\mathrm{H}_{2} \mathrm{~S}$ donor, $\mathrm{NaHS}$, was employed and exerted protective effects likely through anti-inflammatory, antiapoptotic, and anti-oxidative responses. Comparing with new generation synthetic $\mathrm{H}_{2} \mathrm{~S}$ donors like GYY4137, NaHS is less physiologically accurate H2S producer (Li et al., 2008; Yu et al., 2010). Recently, GYY4137 was shown to attenuate heart damage by inhibiting activation of NF- $\kappa \mathrm{B}$ and MAPK signaling in a rat model of myocardial IRI (Meng et al., 2015a,b). Thus, studies are warranted to study whether slow $\mathrm{H}_{2} \mathrm{~S}$ donors like GYY4137 can protect kidney form IRI. Besides, it is worth noting that AP39, a mitochondrially targeted donor of $\mathrm{H}_{2} \mathrm{~S}$, was recently found to inhibit intracellular ROS formation caused by glucose oxidase and protect kidney from IRI caused damage in rats (Ahmad et al., 2016). The study implies the importance of mitochondria $\mathrm{H}_{2} \mathrm{~S}$ in the pathology of renal IRI which needs to be determined in the future.

\section{$\mathrm{H}_{2} \mathrm{~S}$ in Obstructive Nephropathy}

Obstructive nephropathy is a type of renal injury caused by obstruction of the genitourinary tract. Renal fibrosis after ureteral obstruction is implicated in the development of obstructive nephropathy (Boor et al., 2010). Hu's group showed that ureteral obstruction impaired endogenous production of $\mathrm{H}_{2} \mathrm{~S}$ by reducing the expression level of CBS (Song et al., 2014). Renal fibrosis is attenuated when exogenous $\mathrm{H}_{2} \mathrm{~S}$ is administered suggesting an inhibitory effect of $\mathrm{H}_{2} \mathrm{~S}$ on renal fibrosis (Song et al., 2014). In cultured kidney fibroblast, NaHS is able to inhibit cell proliferation and block the differentiation into myofibroblasts by suppressing transforming growth- $\beta 1$-Smad and MAPK signaling pathways (Song et al., 2014). Furthermore, administration of NaHS also prevents the disruption of renal function caused by ureteral obstruction (Jiang et al., 2014; Song et al., 2014; Dursun et al., 2015). A recent study from Sener's group (Lin et al., 2016) showed that $\mathrm{H}_{2} \mathrm{~S}$ slow releasing donor GYY4137 mitigated cortical loss, inflammatory damage and tubulointerstitial fibrosis in a rat model of obstructive nephropathy. Taken together, these results suggest a potential use of $\mathrm{H}_{2} \mathrm{~S}$ donor as a rescue in obstructive nephropathy.

\section{$\mathrm{H}_{2} \mathrm{~S}$ in Cisplatin Nephrotoxicity}

Cisplatin is a major therapeutic drug for solid tumors, but causes severe nephrotoxicity. Over $30 \%$ of patients receiving high dose cisplatin develop renal dysfunction (Pabla and Dong, 2008). However, effective treatment of cisplatin induced renal failure is still lacking. Extensive research revealed that oxidative stress and inflammatory response are the major driving forces for cisplatin induced renal toxicity (Pabla and Dong, 2008; Peres and da Cunha, 2013). Given the well-known inhibitory effects of $\mathrm{H}_{2} \mathrm{~S}$ on oxidative stress and inflammation (Eowicka and Bełtowski, 2006), it is reasonable to hypothesize that $\mathrm{H}_{2} \mathrm{~S}$ is protective against cisplatin nephrotoxicity. However, the role of $\mathrm{H}_{2} \mathrm{~S}$ is rather controversial due to conflicting data in this field. Coimbra and others (Della Coletta Francescato et al., 2011) firstly showed that cisplatin upregulated the expression level of CSE after 3 days upon cisplatin treatment in a rat model. When PAG was administered with cisplatin, it was found that PAG abolished the upregulation of CSE and rescued cisplatin caused renal damage by suppressing inflammation and apoptosis (Della Coletta Francescato et al., 2011). In contrast to this study, administration of NaHS ameliorates the kidney dysfunction and damage in cisplatin treated rat (Ahangarpour et al., 2014). Liu et al. (2016) recently showed that both CSE and CBS levels were severely decreased upon cisplatin treatment in mouse after 3 days. However, pretreatment with $\mathrm{H}_{2} \mathrm{~S}$ slow releasing donor GYY4137 aggravates cisplatin induced renal damage by increasing inflammatory response (Liu et al., 2016). However, several defects on the use of GYY4137 need to be pointed out in the study. As they used a rather low dose of GYY4137 $(21 \mathrm{mg} / \mathrm{kg})$, it is possible that $\mathrm{H}_{2} \mathrm{~S}$ might be not generated sufficiently (Li et al., 2008; Yu et al., 2010; Meng et al., 2015a,b; Lin et al., 2016). In addition, to rule out the possibility that the chemical backbone of GYY4137 molecule has aggravated cisplatin nephrotoxicity, ZYJ1122 (Lee et al., 2011), a structure analog of GYY4127, should be included for the study. Despite the promising protective effect of $\mathrm{H}_{2} \mathrm{~S}$, however, it is still far from the conclusion that $\mathrm{H}_{2} \mathrm{~S}$ is protective in cisplatin nephrotoxicity. In future, more studies are still needed to further investigate (1) the change of CSE and CBS expression level in a time course dependant manner; (2) the effect of endogenous $\mathrm{H}_{2} \mathrm{~S}$ by using genetic mouse rather than nonspecific CBS/CSE inhibitors; (3) the effect of exogenous $\mathrm{H}_{2} \mathrm{~S}$ by using different $\mathrm{H}_{2} \mathrm{~S}$ (NaHS, GYY4137, AP39) donors in parallel.

\section{$\mathrm{H}_{2} \mathrm{~S}$ IN CHRONIC KIDNEY DISEASE}

Chronic kidney disease is a general term for heterogeneous disorders affecting kidney structure and function. In western countries, it is generally associated with old age, diabetes, hypertension, obesity, and cardiovascular disease (Levey and Coresh, 2012). Diabetic nephropathy and hypertensive nephropathy are considered as presumed pathological entities. The role of $\mathrm{H}_{2} \mathrm{~S}$ in these two types of CKD will be reviewed below. 
TABLE 1 | Comparison of the renal protective effect of $\mathrm{H}_{2} \mathrm{~S}$ against ischemic/reperfusion injury.

\begin{tabular}{|c|c|c|c|c|c|}
\hline Treatment & I/R protocol & Species/tissue & Effects of $\mathrm{H}_{2} \mathrm{~S}$ & Mechanism & Reference \\
\hline $\begin{array}{l}\mathrm{NaHS}(100 \mu \mathrm{mol} / \mathrm{kg} \text {, } \\
\text { i.p., } 30 \text { min prior to } \\
\text { ischemia) }\end{array}$ & I (30 min)/R (24 h) & C57BL/6 mice & Improved renal function & - & Tripatara et al., 2008 \\
\hline $\begin{array}{l}\text { NaHS (1 mg/kg, i.p., } \\
15 \text { min prior to } \\
\text { ischemia) }\end{array}$ & I (30 min)/R (24 h) & C57BL/6 mice & $\begin{array}{l}\text { Improved renal } \\
\text { function; reduced renal } \\
\text { injury, and mortality }\end{array}$ & Anti-oxidation & Bos et al., 2009 \\
\hline $\begin{array}{l}\mathrm{NaHS}(100 \mu \mathrm{g} / \mathrm{kg} \text {, i.p., } \\
15 \text { min prior to } \\
\text { ischemia) }\end{array}$ & I (45 min)/R (6 h) & Sprague-Dawley rat & $\begin{array}{l}\text { Improved renal } \\
\text { function; reduced renal } \\
\text { injury }\end{array}$ & $\begin{array}{l}\text { Anti-oxidation; } \\
\text { anti-apoptosis }\end{array}$ & Tripatara et al., 2009 \\
\hline $\begin{array}{l}\mathrm{NaHS}(500 \mu \mathrm{g} / \mathrm{kg} \text {, i.p., } \\
\text { first dose at } 2 \text { days } \\
\text { after ischemia; then } \\
\text { daily) }\end{array}$ & I (30 min)/R (8 days) & C57BL/6 mice & $\begin{array}{l}\text { Accelerated kidney } \\
\text { recovery and tubular } \\
\text { cell regeneration }\end{array}$ & Anti-oxidation & Xu et al., 2009 \\
\hline $\begin{array}{l}\mathrm{NaHS}(100 \mu \mathrm{mol} / \mathrm{kg} \text {, } \\
\text { topically onto the } \\
\text { kidneys } 15 \mathrm{~min} \text { before } \\
\text { ischemia and } 5 \mathrm{~min} \\
\text { before reperfusion) }\end{array}$ & I (45 min)/R (6 h) & Wistar rat & $\begin{array}{l}\text { Improved renal } \\
\text { function; reduced renal } \\
\text { injury }\end{array}$ & $\begin{array}{l}\text { Anti-apoptosis; } \\
\text { anti-MAPK; anti-NF-kB }\end{array}$ & Simon et al., 2011 \\
\hline $\begin{array}{l}\mathrm{H} 2 \mathrm{~S} \text { (100 ppm, } 30 \text { prior } \\
\text { to ischemia) }\end{array}$ & I (30 min)/R (24 h) & C57BL/6 mice & $\begin{array}{l}\text { Improved renal } \\
\text { function; reduced renal } \\
\text { injury }\end{array}$ & $\begin{array}{l}\text { Induction of } \\
\text { hypometabolism }\end{array}$ & Hunter et al., 2012 \\
\hline $\begin{array}{l}\mathrm{Na}_{2} \mathrm{~S} \text { (initial bolus } \\
0.2 \mathrm{mg} / \mathrm{kg} \text { followed by } \\
\text { continuous i.v. } \\
2 \mathrm{mg} / \mathrm{kg} / \mathrm{h} \text { during the } \\
2 \mathrm{~h} \text { before aortic } \\
\text { occlusion, } 0.5 \mathrm{mg} / \mathrm{kg} / \mathrm{h} \\
\text { during the } 90 \mathrm{~min} \text { of } \\
\text { aortic occlusion, and } \\
1 \mathrm{mg} / \mathrm{kg} / \mathrm{h} \text { during the } \\
\text { 8-h reperfusion period) }\end{array}$ & I (2 h)/R (8 h) & Local pig & $\begin{array}{l}\text { Improved renal } \\
\text { function; reduced renal } \\
\text { injury }\end{array}$ & $\begin{array}{l}\text { Anti-apoptosis; } \\
\text { anti-oxidation; } \\
\text { anti-NF-kB }\end{array}$ & Zhu et al., 2012 \\
\hline $\begin{array}{l}\mathrm{NaHS}(150 \mu \mathrm{mol} / \mathrm{kg} \text {, } \\
\text { i.p., } 30 \mathrm{~min} \text { prior to } \\
\text { ischemia) }\end{array}$ & $\begin{array}{l}\text { I (1 h)/R (2 h); warm } \\
\text { ischemia }\end{array}$ & Lewis rat & $\begin{array}{l}\text { Improved renal } \\
\text { function; reduced renal } \\
\text { injury }\end{array}$ & Anti-inflammation & Bos et al., 2013 \\
\hline $\begin{array}{l}\mathrm{Na}_{2} \mathrm{~S} \text { (i.v.; a bolus of } \\
100 \mu \mathrm{g} / \mathrm{kg} \text { was given } \\
10 \mathrm{~min} \text { before } \\
\text { reperfusion, followed by } \\
\text { an infusion of } 1 \mathrm{mg} / \mathrm{kg} \\
\text { given continuously for } \\
30 \text { min after } \\
\text { reperfusion) }\end{array}$ & I (1 h)/R (7 days) & Large white pig & $\begin{array}{l}\text { Improved renal } \\
\text { function; reduced renal } \\
\text { injury }\end{array}$ & Anti-inflammation & Azizi et al., 2015 \\
\hline $\begin{array}{l}\text { NaHS ( } 75 \mu \mathrm{mol} / \mathrm{kg} \text {; i.p.; } \\
10 \text { min prior to } \\
\text { ischemia and } \\
\text { immediately before } \\
\text { reperfusion) }\end{array}$ & I (55 min)/R (24 h) & Wistar rat & $\begin{array}{l}\text { Improved renal } \\
\text { function; reduced renal } \\
\text { injury }\end{array}$ & $\begin{array}{l}\text { Anti-apoptosis; } \\
\text { anti-oxidation }\end{array}$ & Han et al., 2015 \\
\hline $\begin{array}{l}\text { AP39 (0.3 mg/kg; i.p.; } \\
5 \text { min before } \\
\text { reperfusion) }\end{array}$ & I (30 min)/R (24 h) & Sprague-Dawley rat & $\begin{array}{l}\text { Improved renal } \\
\text { function; reduced renal } \\
\text { injury }\end{array}$ & $\begin{array}{l}\text { Anti-apoptosis; } \\
\text { anti-oxidation }\end{array}$ & Ahmad et al., 2016 \\
\hline
\end{tabular}

i.p., intraperitoneal; i.v., intravenous; I/R, ischemia/reperfusion; MAPK, mitogen-activated protein kinase.

\section{$\mathrm{H}_{2} \mathrm{~S}$ in Diabetic Nephropathy}

Diabetic nephropathy is the number one leading cause of CKD in western countries. Morphologically, DN is characterized by hypertrophy induced kidney growth and excessive accumulation of extracellular matrix proteins, eventually proceeding to fibrosis of glomerular and tubulointerstitial compartments (Cooper, 1998; Dronavalli et al., 2008). Current evidence suggests an active role of $\mathrm{H}_{2} \mathrm{~S}$ in the pathogenesis of DN. Plasma $\mathrm{H}_{2} \mathrm{~S}$ level in
DN patients is significantly lower than that in non-DN patients undergoing chronic hemodialysis (Li et al., 2014). High urinary sulfate concentration, a reflection of high plasma $\mathrm{H}_{2} \mathrm{~S}$ level, is associated with reduced risk of renal disease progression in type 2 diabetes (van den Born et al., 2016) and slower decline in $\mathrm{Cr}^{51}$ EDTA-assessed GFR in DN patients (Andresdottir et al., 2013). Recent data suggested that the renal expression of $\mathrm{H}_{2} \mathrm{~S}$ producing enzyme CBS and CSE is down-regulated in pancreatic CaMTg 
diabetic mice (Yamamoto et al., 2013), C57BL/KsJ lepr ${ }^{-/-} \mathrm{db} / \mathrm{db}$ mice (Lee et al., 2012), STZ-diabetic rats (Yuan et al., 2011), and Akita diabetic mice (Kundu et al., 2013). Inhibition of CSE with PAG mimics high glucose-induced glomerular podocyte injury (Liu et al., 2015), implying a contributive role of endogenous $\mathrm{H}_{2} \mathrm{~S}$ in DN. The mechanisms underlying CBS and CSE reduction have been also studied. Kundu et al. (2013) showed that MMP-9 was upregulated in Akita diabetic mice along with the reduction of CBS and CSE. When MMP-9 is knocked out, the expression of the two $\mathrm{H}_{2} \mathrm{~S}$ producing enzyme namely CSE and CBS shows a trend toward baseline despite hyperglycemia (Kundu et al., 2013) suggesting that MMP-9 regulates CBS and CSE expression in DN (Figure 3A).

Meanwhile, exogenous $\mathrm{H}_{2} \mathrm{~S}$ has been proved to be effective in in vitro and in vivo DN models. High glucose caused cell proliferation and collagen formation are attenuated by NaHS in cultured messangial cells (Yuan et al., 2011) and tubular cells (Safar and Abdelsalam, 2015). Moreover, NaHS alone (Yuan et al., 2011; Ahmad et al., 2012; Lee et al., 2012; Kundu et al., 2013; Xue et al., 2013; Zhou et al., 2014; Liu et al., 2015; Safar and Abdelsalam, 2015; Qian et al., 2016) or with losartan (Kaur et al., 2015) ameliorates renal dysfunction and fibrosis formation in various DN related animal models. At least three mechanisms (Figure 3B) are implicated in $\mathrm{H}_{2} \mathrm{~S}$ mediated protective effect in DN: (1) Inhibition of ROS formation by activating Nrf2 pathway. Hyperglycemia induces intracellular ROS which upregulates the expression of MMP-9 (Kundu et al., 2013). MMP-9 plays a major role in diabetic renovascular remodeling. In a STZ induced diabetic rat model, $\mathrm{H}_{2} \mathrm{~S}$ was found to reduce high glucose induced oxidative stress by activating the Nrf2 antioxidant pathway and thereby the level of MMP-9 (Zhou et al., 2014); (2) AMPK activation. Matrix protein deposition requires stimulation of protein synthesis. In DN, PI3K/Akt/mTORC1 signaling is activated due to the suppression of AMPK activity (Yuzawa, 2012). The inactivation of AMPK was found to be partially ascribed to the reduction of $\mathrm{H}_{2} \mathrm{~S}$ level (Lee et al., 2012). NaHS dose- and time- dependently activates the phosphorylation of AMPK and inhibits the stimulation of mTOR (Lee et al., 2012). As a result, mTOR mediated protein synthesis is inhibited which partially accounts for the protective effect of $\mathrm{H}_{2} \mathrm{~S}$ in DN. (3) Stimulation of NO formation. Hyperglycemia upregulates NOX4 expression resulting in the generation of intracellular ROS and laminin $\gamma 1$, both of which contribute to renovascular remodeling (Gorin et al., 2015). Expression of NOX4 can be attenuated by
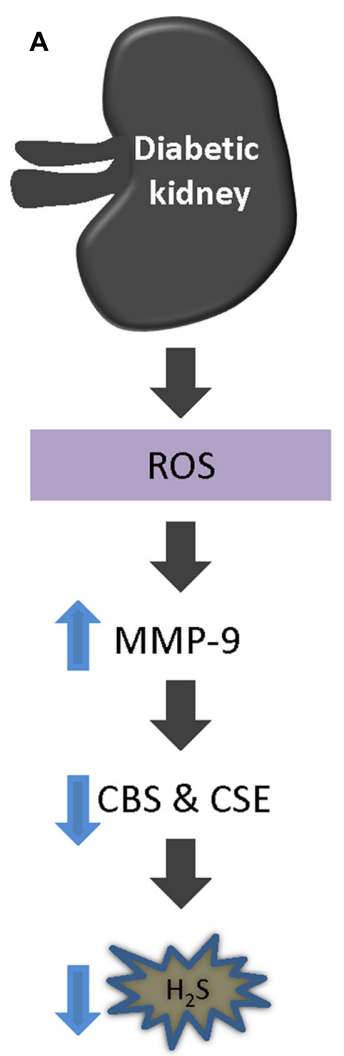

B

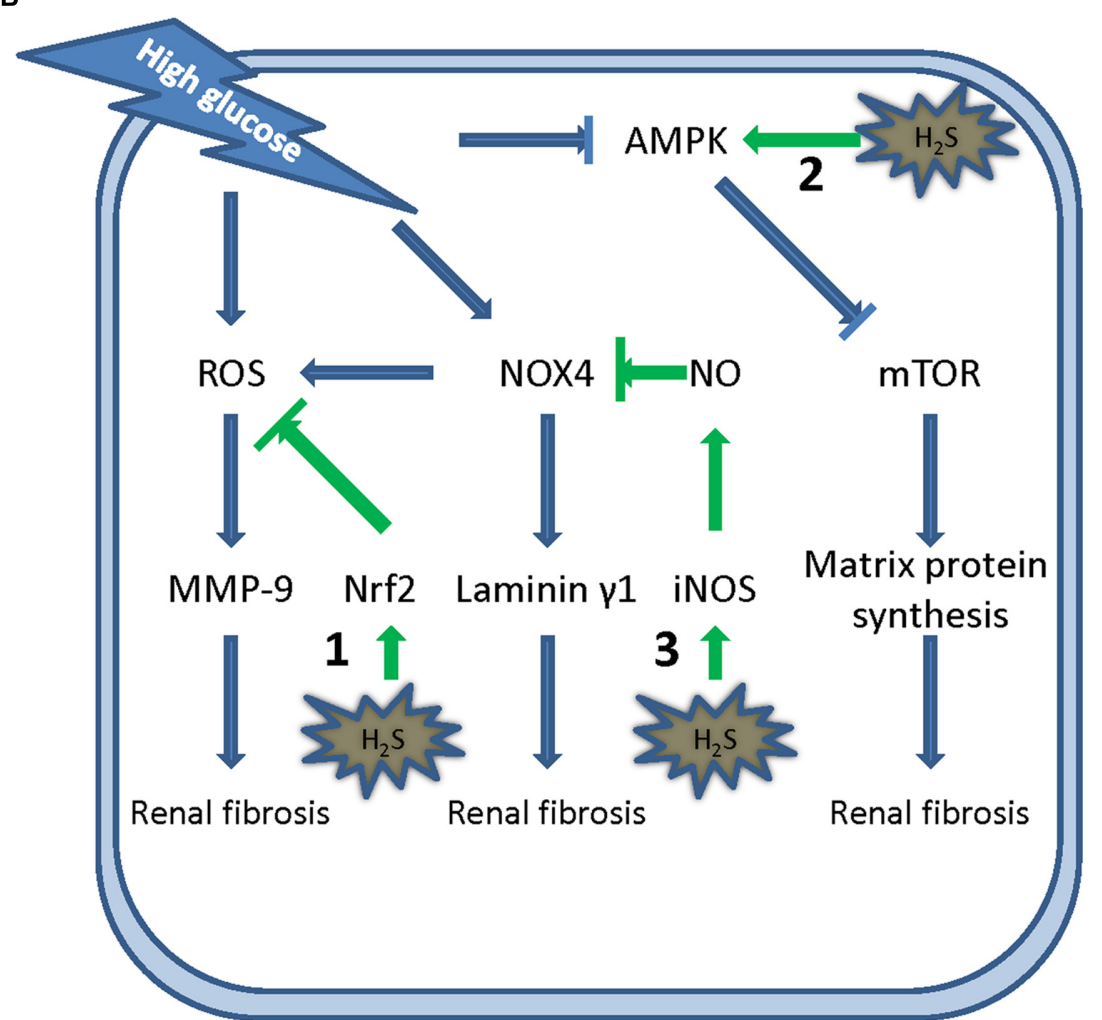

FIGURE 3 | Hydrogen sulfide in DN. (A) ROS mediated MMP-9 up-regulation reduces the level of CBS and CSE in DN. (B) Mechanisms underlying the protective effect of $\mathrm{H}_{2} \mathrm{~S}$ in DN. (1) $\mathrm{H}_{2} \mathrm{~S}$ inhibits ROS formation by activating Nrf2 pathway; (2) $\mathrm{H}_{2} \mathrm{~S}$ activates AMPK, thereby suppressing PI3K/Akt/mTORC1 signaling and subsequent protein synthesis; (3) $\mathrm{H}_{2} \mathrm{~S}$ stimulates NO formation by induction of iNOS expression which inhibits NOX4 level and ROS production. ROS, reactive oxygen species; MMP-9, matrix metalloproteinase-9; AMPK, AMP-activated protein kinase; NO, nitric oxide; iNOS, inducible nitric oxide synthase; mTOR, mechanistic target of rapamycin. 
$\mathrm{H}_{2} \mathrm{~S}$ (Kamat et al., 2015). L-NAME, a NOS inhibitor, abolished the effect of $\mathrm{H}_{2} \mathrm{~S}$ (Feliers et al., 2016). Further study showed that $\mathrm{H}_{2} \mathrm{~S}$ upregulates the protein expression of iNOS but not that of eNOS (Feliers et al., 2016). Moreover, iNOS siRNA can block the effect of $\mathrm{H}_{2} \mathrm{~S}$ (Feliers et al., 2016) suggesting a role for $\mathrm{NO}$ in $\mathrm{H}_{2} \mathrm{~S}$ mediated protective effect in DN. Interestingly, $\mathrm{NO}$ can also stimulate the activity of CSE and $\mathrm{H}_{2} \mathrm{~S}$ production (Nagpure and Bian, 2016) suggesting a cross-talk interaction between these two pathways.

\section{$\mathrm{H}_{2} \mathrm{~S}$ in Hypertensive Nephropathy}

Hypertensive nephropathy, a result of chronic hypertension, is the second leading cause of CKD worldwide (Hart and Bakris, 2010). Long time of high BP load results in damages of kidney, especially in glomerulus. When kidney cannot function properly, it fails to regulate BP. In turn, BP will rise up which further aggravates renal damage (Bidani and Griffin, 2004). Extensive evidence suggests a role of $\mathrm{H}_{2} \mathrm{~S}$ in BP control. Genetic deletion of CSE causes hypertension and diminished endothelium dependent vasorelaxation (Yang et al., 2008). Similar with this, inhibition of both CBS and CSE also increases BP in rat (Roy et al., 2012). These data implies that $\mathrm{H}_{2} \mathrm{~S}$ is a physiologic regulator of BP. Further studies suggest that $\mathrm{H}_{2} \mathrm{~S}$ functions as both an EDHF (Mustafa et al., 2011; Edwards et al., 2012; Tang et al., 2013) and an EDRF (Wang, 2009). The BP lowering effect of exogenous $\mathrm{H}_{2} \mathrm{~S}$ has been subsequently determined. Our group first showed that $\mathrm{H}_{2} \mathrm{~S}$ donor, $\mathrm{NaHS}$, attenuated BP by inhibiting plasma renin activity in a $2 \mathrm{~K} 1 \mathrm{C}$ rat model (Lu et al., 2010). Thereafter, NaHS was demonstrated to reduce BP in spontaneous hypertensive rats (Ahmad et al., 2014), angiotensin II treated mice (Al-Magableh et al., 2015), and sFlt transgenic mice (Holwerda et al., 2014). Additionally, renal protective effects of $\mathrm{H}_{2} \mathrm{~S}$ have also been reported in hypertensive nephropathy. sFlt overexpression in mouse results in hypertension with proteinuria and glomerular endothelosis, all of which are apparently attenuated by administration of NaHS (Holwerda et al., 2014). Further study suggests an involvement of VEGF in this $\mathrm{H}_{2} \mathrm{~S}$ mediated effect (Holwerda et al., 2014). Both $\mathrm{H}_{2} \mathrm{~S}$ and tempol were found to alleviate renal dysfunction in a spontaneous hypertensive rat model by suppressing ROS formation (Ahmad et al., 2014). Recently, Jin's group reported that either NaHS or its metabolite sodium thiosulfate attenuated angiotensin II induced proteinuria, renal dysfunction, and structural deterioration in rat (Al-Magableh et al., 2015). Further studies suggested that the renal effects of $\mathrm{H}_{2} \mathrm{~S}$ were partially mediated by suppression of epithelial sodium channel (Zhang et al., 2013; Wang et al., 2015). Taken together, $\mathrm{H}_{2} \mathrm{~S}$ might be an ideal candidate for the treatment of hypertensive nephropathy.

\section{FUTURE DIRECTIONS}

\section{Role of Mitochondrial $\mathrm{H}_{2} \mathrm{~S}$ Pathway in Kidney Diseases}

In contrast to the extensive studies on CBS and CSE in various kidney diseases, the role of 3-MST is largely neglected although definitive evidence has demonstrated its abundance in kidney (Aminzadeh and Vaziri, 2012; Shibuya et al., 2013; Kimura, 2014). 3-MST resides in mitochondria and is the major producer of mitochondria derived $\mathrm{H}_{2} \mathrm{~S}$. 3-MST silencing was reported to reduce bioenergetic parameters and $\mathrm{H}_{2} \mathrm{~S}$ can serve as an electron donor in mammalian cells (Modis et al., 2013), indicating a possible physiological role of 3-MST/ $\mathrm{H}_{2} \mathrm{~S}$ pathway in maintaining mitochondrial electron transport and cellular bioenergitics. Renal ischemia is the most common cause of acute kidney injury. Hypoxia leads to the inhibition of mitochondrial respiratory chain by deprivation of $\mathrm{O}_{2}$. What will happen if $\mathrm{H}_{2} \mathrm{~S}$ is supplemented into the mitochondria when hypoxia occurs? Szabo's group (Ahmad et al., 2016) showed that mitochondrially targeted $\mathrm{H}_{2} \mathrm{~S}$ donor AP39 ameliorated renal damage in an ischemia/reperfusion rat model, suggesting possible involvement of $3-\mathrm{MST} / \mathrm{H}_{2} \mathrm{~S}$ pathway in the pathogenesis although the change of 3-MST level and activity upon hypoxia was not determined. Additionally, the importance of $3-\mathrm{MST} / \mathrm{H}_{2} \mathrm{~S}$ pathway is also suggested by the fact that ROS, the common cause of renal diseases of all types, induces the translocation of CBS and CSE into mitochondria (Fu et al., 2012). Thus, the revelation of the involvement of 3-MST in kidney diseases is of great value.

\section{Targeting DAO/3-MST Pathway for $\mathrm{H}_{2} \mathrm{~S}$ Delivery to Kidney}

Safety is always a concern when administrating $\mathrm{H}_{2} \mathrm{~S}$ systemically due to its well-known toxicity (Guidotti, 2010; Hirose, 2010) which might hamper its development as therapeutics. This safety issue might be diminished by specific delivery of $\mathrm{H}_{2} \mathrm{~S}$ to the targeted organs. Unfortunately, such organ specific $\mathrm{H}_{2} \mathrm{~S}$ donor is not reported. The discovery of DAO/3-MST pathway might provide a clue about how to deliver $\mathrm{H}_{2} \mathrm{~S}$ specifically into the kidney. The pathway uniquely utilizes $\mathrm{D}$-cysteine rather than L-cystein to produce $\mathrm{H}_{2} \mathrm{~S}$ and exclusively exists in cerebellum and kidney (Shibuya et al., 2013). When D-cysteine is given, it attenuates IRI in kidney with higher potency than L-cysteine (Shibuya et al., 2013). As $\mathrm{H}_{2} \mathrm{~S}$ is broadly renal protective as we have reviewed above, $\mathrm{D}$-cysteine might also ameliorate other renal diseases. Direct administration of $\mathrm{D}$-cysteine induces the generation of $\mathrm{H}_{2} \mathrm{~S}$ in both cerebellum and kidney (Shibuya et al., 2013). Nevertheless, it is possible that structural modification of $\mathrm{D}$-cysteine can generate a novel moiety providing $\mathrm{D}$-cysteine to kidney but not cerebellum due to the impermeability of bloodbrain barrier. This hypothesis warrants further investigation.

\section{Test of Drug-Like $\mathrm{H}_{2} \mathrm{~S}$ Donors in Kidney Disease}

To date, most studies of $\mathrm{H}_{2} \mathrm{~S}$ effect in kidney have been largely restricted to the use of $\mathrm{NaHS}$ as an $\mathrm{H}_{2} \mathrm{~S}$ donor despite of rare exceptions with GYY4137 or AP39. However, NaHS releases $\mathrm{H}_{2} \mathrm{~S}$ at an uncontrolled manner (Li et al., 2008) and is unlikely to be a therapeutic agent (Szabo, 2007). Numerous drug-like $\mathrm{H}_{2} \mathrm{~S}$ donors have been developed and some of them are under the investigation in clinical trials. For instance, an orally active $\mathrm{H}_{2} \mathrm{~S}$ donor SG-1002 is proven to be safe in humans and underwent Phase II study for heart failure (ClinicalTrials.gov identifier: NCT01989208); Antibe Therapeutics are conducting several 
preclinical or clinical studies with their various $\mathrm{H}_{2} \mathrm{~S}$ donors (ATB-346 for osteoarthritis; ATB-352 for Acute pain; ATB-350 for Thrombosis). The information on these $\mathrm{H}_{2} \mathrm{~S}$ releasing donors can be found in Wallace and Wang (2015). Testing of these druglike $\mathrm{H}_{2} \mathrm{~S}$ donors will not only consolidate the protective effect of $\mathrm{H}_{2} \mathrm{~S}$, but also shed light on the translation of $\mathrm{H}_{2} \mathrm{~S}$ as a therapeutic agent for renal diseases.

\section{Understanding the Molecular Mechanism of $\mathrm{H}_{2} \mathrm{~S}$}

Last, but not least, one should bear in mind that the molecular mechanisms underlying $\mathrm{H}_{2} \mathrm{~S}$ effect is still not well-understood. It seems that $\mathrm{H}_{2} \mathrm{~S}$ may partially exert its effect as a reducing agent to eliminate ROS (Bruce King, 2013), while its effects on gene expression may be related to specific molecular targets like NF- $\kappa B$ and the ERK pathways (Oh et al., 2006). However, the molecular details are still unclear. Thus, the in-depth portrayal about the interaction between $\mathrm{H}_{2} \mathrm{~S}$ and its target protein will be interesting.

\section{CONCLUSION}

After recognition as the third gaseous mediator after $\mathrm{NO}$ and $\mathrm{CO}$, the biological actions of $\mathrm{H}_{2} \mathrm{~S}$ are still expanding. In kidney, it

\section{REFERENCES}

Abe, K., and Kimura, H. (1996). The possible role of hydrogen sulfide as an endogenous neuromodulator. J. Neurosci. 16, 1066-1071.

Ahangarpour, A., Abdollahzade Fard, A., Gharibnaseri, M. K., Jalali, T., and Rashidi, I. (2014). Hydrogen sulfide ameliorates the kidney dysfunction and damage in cisplatin-induced nephrotoxicity in rat. Vet. Res. Forum 5, 121-127.

Ahmad, A., Olah, G., Szczesny, B., Wood, M. E., Whiteman, M., and Szabo, C. (2016). AP39, A mitochondrially targeted hydrogen sulfide donor, exerts protective effects in renal epithelial cells subjected to oxidative stress in vitro and in acute renal injury in vivo. Shock 45, 88-97. doi: 10.1097/SHK.0000000000000478

Ahmad, F. U., Sattar, M. A., Rathore, H. A., Abdullah, M. H., Tan, S., Abdullah, N. A., et al. (2012). Exogenous hydrogen sulfide (H2S) reduces blood pressure and prevents the progression of diabetic nephropathy in spontaneously hypertensive rats. Ren. Fail. 34, 203-210. doi: 10.3109/0886022X.2011.643365

Ahmad, F. U., Sattar, M. A., Rathore, H. A., Tan, Y. C., Akhtar, S., Jin, O. H., et al. (2014). Hydrogen sulphide and tempol treatments improve the blood pressure and renal excretory responses in spontaneously hypertensive rats. Ren. Fail. 36, 598-605. doi: 10.3109/0886022X.2014.882218

Al-Magableh, M. R., Kemp-Harper, B. K., and Hart, J. L. (2015). Hydrogen sulfide treatment reduces blood pressure and oxidative stress in angiotensin II-induced hypertensive mice. Hypertens. Res. 38, 13-20. doi: 10.1038/hr.2014.125

Aminzadeh, M. A., and Vaziri, N. D. (2012). Downregulation of the renal and hepatic hydrogen sulfide (H2S)-producing enzymes and capacity in chronic kidney disease. Nephrol. Dial. Transplant. 27, 498-504. doi: 10.1093/ndt/gfr560

Andresdottir, G., Bakker, S. J., Hansen, H. P., Parving, H. H., and Rossing, P. (2013). Urinary sulphate excretion and progression of diabetic nephropathy in Type 1 diabetes. Diabet. Med. 30, 563-566. doi: 10.1111/dme.12131

Azizi, F., Seifi, B., Kadkhodaee, M., and Ahghari, P. (2015). Administration of hydrogen sulfide protects ischemia reperfusion-induced acute kidney injury by reducing the oxidative stress. Ir. J. Med. Sci. 185, 649-654. doi: 10.1007/s11845015-1328-z

Bellomo, R., Kellum, J. A., and Ronco, C. (2012). Acute kidney injury. Lancet 380, 756-766. doi: 10.1016/S0140-6736(11)61454-2 is actively participating in the renal regulation in physiological condition. Due to the regulatory role of kidney in the body, it is possible that $\mathrm{H}_{2} \mathrm{~S}$ has far-reaching actions by modulating renal function which needs to be uncovered. Because of the significant role of $\mathrm{H}_{2} \mathrm{~S}$ in renal physiology, it is not surprising that dysfunction of $\mathrm{H}_{2} \mathrm{~S}$ contributes to the pathogenesis of kidney related diseases. Thereafter, administration of $\mathrm{H}_{2} \mathrm{~S}$ mainly with $\mathrm{NaHS}$ was proven to rescue kidney damages in animal models with various types of kidney diseases. In the future, drug like $\mathrm{H}_{2} \mathrm{~S}$ donors need to be tested to translate $\mathrm{H}_{2} \mathrm{~S}$ as a treatment for renal diseases in clinical. Besides, in-depth studies of $\mathrm{H}_{2} \mathrm{~S}$ mediated molecular actions are also needed to complete our understanding of the role of $\mathrm{H}_{2} \mathrm{~S}$ in both renal physiology and pathology.

\section{AUTHOR CONTRIBUTIONS}

All authors listed, have made substantial, direct and intellectual contribution to the work, and approved it for publication.

\section{FUNDING}

This work was supported by grants from NMRC/CIRG/1432/2015 and NUHSRO/2011/012/STB/B2B-08.

Beltowski, J. (2010). Hypoxia in the renal medulla: implications for hydrogen sulfide signaling. J. Pharmacol. Exp. Ther. 334, 358-363. doi: 10.1124/jpet.110.166637

Bidani, A. K., and Griffin, K. A. (2004). Pathophysiology of hypertensive renal damage: implications for therapy. Hypertension 44, 595-601. doi: 10.1161/01.HYP.0000145180.38707.84

Boor, P., Ostendorf, T., and Floege, J. (2010). Renal fibrosis: novel insights into mechanisms and therapeutic targets. Nat. Rev. Nephrol. 6, 643-656. doi: 10.1038/nrneph.2010.120

Bos, E. M., Leuvenink, H. G., Snijder, P. M., Kloosterhuis, N. J., Hillebrands, J. L., Leemans, J. C., et al. (2009). Hydrogen sulfide-induced hypometabolism prevents renal ischemia/reperfusion injury. J. Am. Soc. Nephrol. 20, 1901-1905. doi: 10.1681/ASN.2008121269

Bos, E. M., Wang, R., Snijder, P. M., Boersema, M., Damman, J., Fu, M., et al. (2013). Cystathionine gamma-lyase protects against renal ischemia/reperfusion by modulating oxidative stress. J. Am. Soc. Nephrol. 24, 759-770. doi: 10.1681/ASN.2012030268

Bruce King, S. (2013). Potential biological chemistry of hydrogen sulfide (H2S) with the nitrogen oxides. Free Radic. Biol. Med. 55, 1-7. doi: 10.1016/j.freeradbiomed.2012.11.005

Cooper, M. E. (1998). Pathogenesis, prevention, and treatment of diabetic nephropathy. Lancet 352, 213-219. doi: 10.1016/S0140-6736(05)79820-2

Della Coletta Francescato, H., Cunha, F. Q., Costa, R. S., Barbosa Junior, F., Boim, M. A., Arnoni, C. P., et al. (2011). Inhibition of hydrogen sulphide formation reduces cisplatin-induced renal damage. Nephrol. Dial. Transplant. 26, 479-488. doi: 10.1093/ndt/gfq447

Dombkowski, R. A., Naylor, M. G., Shoemaker, E., Smith, M., DeLeon, E. R., Stoy, G. F., et al. (2011). Hydrogen sulfide $(\mathrm{H}(2) \mathrm{S})$ and hypoxia inhibit salmonid gastrointestinal motility: evidence for $\mathrm{H}(2) \mathrm{S}$ as an oxygen sensor. J. Exp. Biol. 214(Pt 23), 4030-4040. doi: 10.1242/jeb.061473

Dronavalli, S., Duka, I., and Bakris, G. L. (2008). The pathogenesis of diabetic nephropathy. Nat. Clin. Pract. Endocrinol. Metab. 4, 444-452. doi: $10.1038 /$ ncpendmet0894

Dursun, M., Otunctemur, A., Ozbek, E., Sahin, S., Besiroglu, H., Ozsoy, O. D., et al. (2015). Protective effect of hydrogen sulfide on renal injury in the 
experimental unilateral ureteral obstruction. Int. Braz. J. Urol. 41, 1185-1193. doi: 10.1590/S1677-5538.IBJU.2014.0090

Edwards, G., Feletou, M., and Weston, A. H. (2012). Hydrogen sulfide as an endothelium-derived hyperpolarizing factor in rodent mesenteric arteries. Circ. Res. 110, e13-e14.

Eltzschig, H. K., and Eckle, T. (2011). Ischemia and reperfusion [mdash] from mechanism to translation. Nat. Med. 17, 1391-1401.

Feliers, D., Lee, H. J., and Kasinath, B. S. (2016). Hydrogen sulfide in renal physiology and disease. Antioxid. Redox Signal. doi: 10.1089/ars.2015.6596 [Epub ahead of print].

Fu, M., Zhang, W., Wu, L., Yang, G., Li, H., and Wang, R. (2012). Hydrogen sulfide (H2S) metabolism in mitochondria and its regulatory role in energy production. Proc. Natl. Acad. Sci. U.S.A. 109, 2943-2948. doi: 10.1073/pnas.1115634109

Gambaryan, S., Wagner, C., Smolenski, A., Walter, U., Poller, W., Haase, W., et al. (1998). Endogenous or overexpressed cGMP-dependent protein kinases inhibit cAMP-dependent renin release from rat isolated perfused kidney, microdissected glomeruli, and isolated juxtaglomerular cells. Proc. Natl. Acad. Sci. U.S.A. 95, 9003-9008. doi: 10.1073/pnas.95.15.9003

Ge, S. N., Zhao, M. M., Wu, D. D., Chen, Y., Wang, Y., Zhu, J. H., et al. (2014). Hydrogen sulfide targets EGFR Cys797/Cys798 residues to induce $\mathrm{Na}(+) / \mathrm{K}(+)$-ATPase endocytosis and inhibition in renal tubular epithelial cells and increase sodium excretion in chronic salt-loaded rats. Antioxid. Redox Signal. 21, 2061-2082. doi: 10.1089/ars.2013.5304

Gorin, Y., Cavaglieri, R. C., Khazim, K., Lee, D. Y., Bruno, F., Thakur, S., et al. (2015). Targeting NADPH oxidase with a novel dual Nox1/Nox4 inhibitor attenuates renal pathology in type 1 diabetes. Am. J. Physiol. Renal Physiol. 308, F1276-F1287. doi: 10.1152/ajprenal.00396.2014

Guidotti, T. L. (2010). Hydrogen sulfide: advances in understanding human toxicity. Int. J. Toxicol. 29, 569-581. doi: 10.1177/1091581810384882

Han, S. J., Kim, J. I., Park, J. W., and Park, K. M. (2015). Hydrogen sulfide accelerates the recovery of kidney tubules after renal ischemia/reperfusion injury. Nephrol. Dial. Transplant. 30, 1497-1506. doi: 10.1093/ndt/gfv226

Hart, P. D., and Bakris, G. L. (2010). Hypertensive nephropathy: prevention and treatment recommendations. Expert Opin. Pharmacother. 11, 2675-2686. doi: $10.1517 / 14656566.2010 .485612$

Hirose, Y. (2010). [Clinical aspects of hydrogen sulfide poisoning]. Chudoku Kenkyu 23, 212-216.

Holwerda, K. M., Burke, S. D., Faas, M. M., Zsengeller, Z., Stillman, I. E., Kang, P. M., et al. (2014). Hydrogen sulfide attenuates sFlt1-induced hypertension and renal damage by upregulating vascular endothelial growth factor. J. Am. Soc. Nephrol. 25, 717-725. doi: 10.1681/ASN.2013030291

House, J. D., Brosnan, M. E., and Brosnan, J. T. (1997). Characterization of homocysteine metabolism in the rat kidney. Biochem. J. 328(Pt 1), 287-292.

Hu, H., Shi, Y., Chen, Q., Yang, W., Zhou, H., Chen, L., et al. (2008). Endogenous hydrogen sulfide is involved in regulation of respiration in medullary slice of neonatal rats. Neuroscience 156, 1074-1082. doi: 10.1016/j.neuroscience.2008.08.025

Hunter, J. P., Hosgood, S. A., Patel, M., Rose, R., Read, K., and Nicholson, M. L. (2012). Effects of hydrogen sulphide in an experimental model of renal ischaemia-reperfusion injury. Br. J. Surg. 99, 1665-1671. doi: 10.1002/bjs.8956

Ishii, I., Akahoshi, N., Yu, X. N., Kobayashi, Y., Namekata, K., Komaki, G., et al. (2004). Murine cystathionine gamma-lyase: complete cDNA and genomic sequences, promoter activity, tissue distribution and developmental expression. Biochem. J. 381(Pt 1), 113-123.

Jiang, D., Zhang, Y., Yang, M., Wang, S., Jiang, Z., and Li, Z. (2014). Exogenous hydrogen sulfide prevents kidney damage following unilateral ureteral obstruction. Neurourol. Urodyn. 33, 538-543. doi: 10.1002/nau.22450

Kamat, P. K., Kalani, A., Tyagi, S. C., and Tyagi, N. (2015). Hydrogen sulfide epigenetically attenuates homocysteine-induced mitochondrial toxicity mediated through NMDA receptor in mouse brain endothelial (bEnd3) cells. J. Cell. Physiol. 230, 378-394. doi: 10.1002/jcp.24722

Kaur, M., Sachdeva, S., Bedi, O., Kaur, T., and Kumar, P. (2015). Combined effect of hydrogen sulphide donor and losartan in experimental diabetic nephropathy in rats. J. Diabetes Metab. Disord. 14:63. doi: 10.1186/s40200-015-0212-8

Kimura, H. (2011). Hydrogen sulfide: its production, release and functions. Amino Acids 41, 113-121. doi: 10.1007/s00726-010-0510-x

Kimura, H. (2014). The physiological role of hydrogen sulfide and beyond. Nitric Oxide 41, 4-10. doi: 10.1016/j.niox.2014.01.002
Koning, A. M., Frenay, A. R., Leuvenink, H. G., and van Goor, H. (2015). Hydrogen sulfide in renal physiology, disease and transplantation-the smell of renal protection. Nitric Oxide 46, 37-49. doi: 10.1016/j.niox.2015.01.005

Kundu, S., Pushpakumar, S. B., Tyagi, A., Coley, D., and Sen, U. (2013). Hydrogen sulfide deficiency and diabetic renal remodeling: role of matrix metalloproteinase-9. Am. J. Physiol. Endocrinol. Metab. 304, E1365-E1378. doi: 10.1152/ajpendo.00604.2012

Lee, H. J., Mariappan, M. M., Feliers, D., Cavaglieri, R. C., Sataranatarajan, K., Abboud, H. E., et al. (2012). Hydrogen sulfide inhibits high glucose-induced matrix protein synthesis by activating AMP-activated protein kinase in renal epithelial cells. J. Biol. Chem. 287, 4451-4461. doi: 10.1074/jbc.M111.278325

Lee, S. W., Cheng, Y., Moore, P. K., and Bian, J. S. (2007). Hydrogen sulphide regulates intracellular $\mathrm{pH}$ in vascular smooth muscle cells. Biochem. Biophys. Res. Commun. 358, 1142-1147. doi: 10.1016/j.bbrc.2007.04.203

Lee, Z. W., Zhou, J., Chen, C. S., Zhao, Y., Tan, C. H., Li, L., et al. (2011). The slowreleasing hydrogen sulfide donor, GYY4137, exhibits novel anti-cancer effects in vitro and in vivo. PLoS ONE 6:e21077. doi: 10.1371/journal.pone.0021077

Levey, A. S., and Coresh, J. (2012). Chronic kidney disease. Lancet 379, 165-180. doi: 10.1016/S0140-6736(11)60178-5

Li, H., Feng, S. J., Zhang, G. Z., and Wang, S. X. (2014). Correlation of lower concentrations of hydrogen sulfide with atherosclerosis in chronic hemodialysis patients with diabetic nephropathy. Blood Purif. 38, 188-194. doi: $10.1159 / 000368883$

Li, L., Hsu, A., and Moore, P. K. (2009). Actions and interactions of nitric oxide, carbon monoxide and hydrogen sulphide in the cardiovascular system and in inflammation-a tale of three gases! Pharmacol. Ther. 123, 386-400. doi: 10.1016/j.pharmthera.2009.05.005

Li, L., Whiteman, M., Guan, Y. Y., Neo, K. L., Cheng, Y., Lee, S. W., et al. (2008). Characterization of a novel, water-soluble hydrogen sulfide-releasing molecule (GYY4137): new insights into the biology of hydrogen sulfide. Circulation 117, 2351-2360. doi: 10.1161/CIRCULATIONAHA.107.753467

Li, N., Chen, L., Muh, R. W., and Li, P. L. (2006). Hyperhomocysteinemia associated with decreased renal transsulfuration activity in Dahl S rats. Hypertension 47, 1094-1100. doi: 10.1161/01.HYP.0000217972.80731.ef

Lim, J. J., Liu, Y. H., Khin, E. S., and Bian, J. S. (2008). Vasoconstrictive effect of hydrogen sulfide involves downregulation of cAMP in vascular smooth muscle cells. Am. J. Physiol. Cell Physiol. 295, C1261-C1270. doi: 10.1152/ajpcell.00195.2008

Lin, S., Visram, F., Liu, W., Haig, A., Jiang, J., Mok, A., et al. (2016). GYY4137, a slow-releasing hydrogen sulfide donor, ameliorates renal damage associated with chronic obstructive uropathy. J. Urol. doi: 10.1016/j.juro.2016.05.029 [Epub ahead of print].

Liu, M., Jia, Z., Sun, Y., Zhang, A., and Yang, T. (2016). A H 2 S donor GYY4137 exacerbates cisplatin-induced nephrotoxicity in mice. Mediators Inflamm. 2016:8145785. doi: 10.1155/2016/8145785

Liu, Y., Zhao, H., Qiang, Y., Qian, G., Lu, S., Chen, J., et al. (2015). Effects of hydrogen sulfide on high glucose-induced glomerular podocyte injury in mice. Int. J. Clin. Exp. Pathol. 8, 6814-6820.

Liu, Y. H., and Bian, J. S. (2010). Bicarbonate-dependent effect of hydrogen sulfide on vascular contractility in rat aortic rings. Am. J. Physiol. Cell Physiol. 299, C866-C872. doi: 10.1152/ajpcell.00105.2010

Liu, Y. H., Lu, M., Hu, L. F., Wong, P. T., Webb, G. D., and Bian, J. S. (2012). Hydrogen sulfide in the mammalian cardiovascular system. Antioxid. Redox. Signal. 17, 141-185. doi: 10.1089/ars.2011.4005

Łowicka, E., and Bełtowski, J. (2006). Hydrogen sulfide (H2S)-the third gas of interest for pharmacologists. Pharmacol. Rep. 59, 4-24.

Lu, M., Liu, Y. H., Goh, H. S., Wang, J. J., Yong, Q. C., Wang, R., et al. (2010). Hydrogen sulfide inhibits plasma renin activity. J. Am. Soc. Nephrol. 21, 9931002. doi: 10.1681/ASN.2009090949

Lu, M., Liu, Y. H., Ho, C. Y., Tiong, C. X., and Bian, J. S. (2012). Hydrogen sulfide regulates cAMP homeostasis and renin degranulation in As4.1 and rat renin-rich kidney cells. Am. J. Physiol. Cell Physiol. 302, C59-C66. doi: 10.1152/ajpcell.00341.2010

Mathai, J. C., Missner, A., Kugler, P., Saparov, S. M., Zeidel, M. L., Lee, J. K., et al. (2009). No facilitator required for membrane transport of hydrogen sulfide. Proc. Natl. Acad. Sci. U.S.A. 106, 16633-16638. doi: 10.1073/pnas.0902952106

Meng, G., Wang, J., Xiao, Y., Bai, W., Xie, L., Shan, L., et al. (2015a). GYY4137 protects against myocardial ischemia and reperfusion injury by attenuating 
oxidative stress and apoptosis in rats. J. Biomed. Res. 29, 203-213. doi: 10.7555/JBR.28.20140037

Meng, G., Zhu, J., Xiao, Y., Huang, Z., Zhang, Y., Tang, X., et al. (2015b). Hydrogen sulfide donor GYY4137 protects against myocardial fibrosis. Oxid. Med. Cell. Longev. 2015:691070. doi: 10.1155/2015/691070

Modis, K., Coletta, C., Erdelyi, K., Papapetropoulos, A., and Szabo, C. (2013). Intramitochondrial hydrogen sulfide production by 3-mercaptopyruvate sulfurtransferase maintains mitochondrial electron flow and supports cellular bioenergetics. FASEB J. 27, 601-611. doi: 10.1096/fj.12-216507

Mustafa, A. K., Sikka, G., Gazi, S. K., Steppan, J., Jung, S. M., Bhunia, A. K., et al. (2011). Hydrogen sulfide as endothelium-derived hyperpolarizing factor sulfhydrates potassium channels. Circ. Res. 109, 1259-1268. doi: 10.1161/CIRCRESAHA.111.240242

Nagpure, B. V., and Bian, J. S. (2016). Interaction of Hydrogen Sulfide with Nitric Oxide in the Cardiovascular System. Oxid. Med. Cell. Longev. 2016:6904327. doi: $10.1155 / 2016 / 6904327$

Nicholson, R. A., Roth, S. H., Zhang, A., Zheng, J., Brookes, J., Skrajny, B., et al. (1998). Inhibition of respiratory and bioenergetic mechanisms by hydrogen sulfide in mammalian brain. J. Toxicol. Environ. Health A 54, 491-507. doi: 10.1080/009841098158773

Oh, G. S., Pae, H. O., Lee, B. S., Kim, B. N., Kim, J. M., Kim, H. R., et al. (2006). Hydrogen sulfide inhibits nitric oxide production and nuclear factor-kappaB via heme oxygenase-1 expression in RAW264.7 macrophages stimulated with lipopolysaccharide. Free Radic. Biol. Med. 41, 106-119. doi: 10.1016/j.freeradbiomed.2006.03.021

Olson, K. R. (2015). Hydrogen sulfide as an oxygen sensor. Antioxid. Redox Signal. 22, 377-397. doi: 10.1089/ars.2014.5930

Olson, K. R., Dombkowski, R. A., Russell, M. J., Doellman, M. M., Head, S. K., Whitfield, N. L., et al. (2006). Hydrogen sulfide as an oxygen sensor/transducer in vertebrate hypoxic vasoconstriction and hypoxic vasodilation. J. Exp. Biol. 209(Pt 20), 4011-4023. doi: 10.1242/jeb.02480

Olson, K. R., and Whitfield, N. L. (2010). Hydrogen sulfide and oxygen sensing in the cardiovascular system. Antioxid. Redox Signal. 12, 1219-1234. doi: 10.1089/ars.2009.2921

Pabla, N., and Dong, Z. (2008). Cisplatin nephrotoxicity: mechanisms and renoprotective strategies. Kidney Int. 73, 994-1007. doi: 10.1038/sj.ki.5002786

Pan, W. J., Fan, W. J., Zhang, C., Han, D., Qu, S. L., and Jiang, Z. S. (2015). H2S, a novel therapeutic target in renal-associated diseases? Clin. Chim. Acta 438, 112-118. doi: 10.1016/j.cca.2014.08.005

Peres, L. A. B., and da Cunha, A. D. Jr. (2013). Acute nephrotoxicity of cisplatin: molecular mechanisms. J. Bras. Nefrol. 35, 332-340. doi: 10.5935/01012800.20130052

Peters, J., Münter, K., Bader, M., Hackenthal, E., Mullins, J., and Ganten, D. (1993). Increased adrenal renin in transgenic hypertensive rats, TGR (mREN2) 27, and its regulation by cAMP, angiotensin II, and calcium. J. Clin. Invest. 91, 742-747. doi: 10.1172/JCI116292

Qian, X., Li, X., Ma, F., Luo, S., Ge, R., and Zhu, Y. (2016). Novel hydrogen sulfidereleasing compound, S-propargyl-cysteine, prevents STZ-induced diabetic nephropathy. Biochem. Biophys. Res. Commun. 473, 931-938.

Reiffenstein, R. J., Hulbert, W. C., and Roth, S. H. (1992). Toxicology of hydrogen sulfide. Annu. Rev. Pharmacol. Toxicol. 32, 109-134. doi: 10.1146/annurev.pa.32.040192.000545

Roy, A., Khan, A. H., Islam, M. T., Prieto, M. C., and Majid, D. S. (2012). Interdependency of cystathione gamma-lyase and cystathione beta-synthase in hydrogen sulfide-induced blood pressure regulation in rats. Am. J. Hypertens. 25, 74-81. doi: 10.1038/ajh.2011.149

Safar, M. M., and Abdelsalam, R. M. (2015). H2S donors attenuate diabetic nephropathy in rats: modulation of oxidant status and polyol pathway. Pharmacol. Rep. 67, 17-23. doi: 10.1016/j.pharep.2014.08.001

Schweda, F., Friis, U., Wagner, C., Skott, O., and Kurtz, A. (2007). Renin release. Physiology 22, 310-319. doi: 10.1152/physiol.00024.2007

Shibuya, N., Koike, S., Tanaka, M., Ishigami-Yuasa, M., Kimura, Y., Ogasawara, Y., et al. (2013). A novel pathway for the production of hydrogen sulfide from D-cysteine in mammalian cells. Nat. Commun. 4:1366. doi: 10.1038/ncomms 2371

Shibuya, N., Tanaka, M., Yoshida, M., Ogasawara, Y., Togawa, T., Ishii, K., et al. (2009). 3-Mercaptopyruvate sulfurtransferase produces hydrogen sulfide and bound sulfane sulfur in the brain. Antioxid. Redox Signal. 11, 703-714. doi: 10.1089/ARS.2008.2253

Simon, F., Scheuerle, A., Groger, M., Stahl, B., Wachter, U., Vogt, J., et al. (2011). Effects of intravenous sulfide during porcine aortic occlusioninduced kidney ischemia/reperfusion injury. Shock 35, 156-163. doi: 10.1097/SHK.0b013e3181f0dc91

Smith, R. P., and Gosselin, R. E. (1979). Hydrogen sulfide poisoning. J. Occup. Med. 21, 93-97. doi: 10.1097/00043764-197902000-00008

Song, K., Wang, F., Li, Q., Shi, Y. B., Zheng, H. F., Peng, H., et al. (2014). Hydrogen sulfide inhibits the renal fibrosis of obstructive nephropathy. Kidney Int. 85, 1318-1329. doi: 10.1038/ki.2013.449

Stipanuk, M. H. (2004). Sulfur amino acid metabolism: pathways for production and removal of homocysteine and cysteine. Annu. Rev. Nutr. 24, 539-577. doi: 10.1146/annurev.nutr.24.012003.132418

Stipanuk, M. H., and Beck, P. W. (1982). Characterization of the enzymic capacity for cysteine desulphhydration in liver and kidney of the rat. Biochem. J. 206, 267-277.

Stipanuk, M. H., and King, K. M. (1982). Characteristics of the enzymatic capacity for cysteine desulfhydration in cat tissues. Comp. Biochem. Physiol. B 73, 595-601. doi: 10.1016/0300-9629(82)90266-3

Szabo, C. (2007). Hydrogen sulphide and its therapeutic potential. Nat. Rev. Drug Discov. 6, 917-935. doi: 10.1038/nrd2222

Tang, G., Yang, G., Jiang, B., Ju, Y., Wu, L., and Wang, R. (2013). H(2)S is an endothelium-derived hyperpolarizing factor. Antioxid. Redox Signal. 19, 1634-1646. doi: 10.1089/ars.2012.4805

Teng, H., Wu, B., Zhao, K., Yang, G., Wu, L., and Wang, R. (2013). Oxygensensitive mitochondrial accumulation of cystathionine beta-synthase mediated by Lon protease. Proc. Natl. Acad. Sci. U.S.A. 110, 12679-12684. doi: 10.1073/pnas.1308487110

Tripatara, P., Patel, N. S., Brancaleone, V., Renshaw, D., Rocha, J., Sepodes, B., et al. (2009). Characterisation of cystathionine gamma-lyase/hydrogen sulphide pathway in ischaemia/reperfusion injury of the mouse kidney: an in vivo study. Eur. J. Pharmacol. 606, 205-209. doi: 10.1016/j.ejphar.2009.01.041

Tripatara, P., Patel, N. S., Collino, M., Gallicchio, M., Kieswich, J., Castiglia, S., et al. (2008). Generation of endogenous hydrogen sulfide by cystathionine gammalyase limits renal ischemia/reperfusion injury and dysfunction. Lab. Invest. 88, 1038-1048. doi: 10.1038/labinvest.2008.73

van den Born, J. C., Frenay, A. R., Bakker, S. J., Pasch, A., Hillebrands, J. L., Lambers Heerspink, H. J., et al. (2016). High urinary sulfate concentration is associated with reduced risk of renal disease progression in type 2 diabetes. Nitric Oxide 55-56, 18-24. doi: 10.1016/j.niox.2016.03.001

Wallace, J. L., and Wang, R. (2015). Hydrogen sulfide-based therapeutics: exploiting a unique but ubiquitous gasotransmitter. Nat. Rev. Drug Discov. 14, 329-345. doi: 10.1038/nrd4433

Wang, Q., Song, B., Jiang, S., Liang, C., Chen, X., Shi, J., et al. (2015). Hydrogen sulfide prevents advanced glycation end-products induced activation of the epithelial sodium channel. Oxid. Med. Cell. Longev. 2015:976848. doi: $10.1155 / 2015 / 976848$

Wang, R. (2002). Two's company, three's a crowd: can H2S be the third endogenous gaseous transmitter? FASEB J. 16, 1792-1798. doi: 10.1096/fj.02-0211hyp

Wang, R. (2009). Hydrogen sulfide: a new EDRF. Kidney Int. 76, 700-704. doi: 10.1038/ki.2009.221

Warenycia, M. W., Smith, K. A., Blashko, C. S., Kombian, S. B., and Reiffenstein, R. J. (1989). Monoamine oxidase inhibition as a sequel of hydrogen sulfide intoxication: increases in brain catecholamine and 5-hydroxytryptamine levels. Arch. Toxicol. 63, 131-136.

Xia, M., Chen, L., Muh, R. W., Li, P. L., and Li, N. (2009). Production and actions of hydrogen sulfide, a novel gaseous bioactive substance, in the kidneys. $J$. Pharmacol. Exp. Ther. 329, 1056-1062. doi: 10.1124/jpet.108.149963

Xu, Z., Prathapasinghe, G., Wu, N., Hwang, S. Y., Siow, Y. L., and Oh, K. (2009). Ischemia-reperfusion reduces cystathionine-beta-synthase-mediated hydrogen sulfide generation in the kidney. Am. J. Physiol. Renal Physiol. 297, F27-F35. doi: 10.1152/ajprenal.00096.2009

Xue, H., Yuan, P., Ni, J., Li, C., Shao, D., Liu, J., et al. (2013). H(2)S inhibits hyperglycemia-induced intrarenal renin-angiotensin system activation via attenuation of reactive oxygen species generation. PLOS ONE 8:e74366. doi: 10.1371/journal.pone.0074366 
Yamamoto, J., Sato, W., Kosugi, T., Yamamoto, T., Kimura, T., Taniguchi, S., et al. (2013). Distribution of hydrogen sulfide $(\mathrm{H}(2) \mathrm{S})$-producing enzymes and the roles of the $\mathrm{H}(2) \mathrm{S}$ donor sodium hydrosulfide in diabetic nephropathy. Clin. Exp. Nephrol. 17, 32-40. doi: 10.1007/s10157-012-0670-y

Yang, G., Wu, L., Jiang, B., Yang, W., Qi, J., Cao, K., et al. (2008). H2S as a physiologic vasorelaxant: hypertension in mice with deletion of cystathionine gamma-lyase. Science 322, 587-590. doi: 10.1126/science.1162667

Yong, Q. C., Pan, T. T., Hu, L. F., and Bian, J. S. (2008). Negative regulation of betaadrenergic function by hydrogen sulphide in the rat hearts. J. Mol. Cell Cardiol. 44, 701-710. doi: 10.1016/j.yjmcc.2008.01.007

Yu, F., Zhao, J., Tang, C. S., and Geng, B. (2010). [Effect of synthesized GYY4137, a slowly releasing hydrogen sulfide donor, on cell viability and distribution of hydrogen sulfide in mice]. Beijing Da Xue. Xue. Bao 42, 493-497.

Yuan, P., Xue, H., Zhou, L., Qu, L., Li, C., Wang, Z., et al. (2011). Rescue of mesangial cells from high glucose-induced over-proliferation and extracellular matrix secretion by hydrogen sulfide. Nephrol. Dial. Transplant. 26, 2119-2126. doi: $10.1093 / \mathrm{ndt} / \mathrm{gfq} 749$

Yuzawa, Y. (2012). [Role of hydrogen sulfide in chronic kidney disease and diabetic nephropathy]. Nihon Yakurigaku Zasshi 139, 17-21. doi: 10.1254/fpj.139.17

Zhang, J., Chen, S., Liu, H., Zhang, B., Zhao, Y., Ma, K., et al. (2013). Hydrogen sulfide prevents hydrogen peroxide-induced activation of epithelial sodium channel through a PTEN/PI(3,4,5)P3 dependent pathway. PLoS ONE 8:e64304. doi: 10.1371/journal.pone.0064304
Zhang, X., and Bian, J. S. (2014). Hydrogen sulfide: a neuromodulator and neuroprotectant in the central nervous system. ACS Chem. Neurosci. 5, 876-883. doi: 10.1021/cn500185g

Zhou, X., Feng, Y., Zhan, Z., and Chen, J. (2014). Hydrogen sulfide alleviates diabetic nephropathy in a streptozotocin-induced diabetic rat model. J. Biol. Chem. 289, 28827-28834. doi: 10.1074/jbc.M114. 596593

Zhu, J. X., Kalbfleisch, M., Yang, Y. X., Bihari, R., Lobb, I., Davison, M., et al. (2012). Detrimental effects of prolonged warm renal ischaemia-reperfusion injury are abrogated by supplemental hydrogen sulphide: an analysis using realtime intravital microscopy and polymerase chain reaction. BJU Int. 110(11 Pt C), E1218-E1227. doi: 10.1111/j.1464-410X.2012.11555.x

Conflict of Interest Statement: The authors declare that the research was conducted in the absence of any commercial or financial relationships that could be construed as a potential conflict of interest.

Copyright (C) 2016 Cao and Bian. This is an open-access article distributed under the terms of the Creative Commons Attribution License (CC BY). The use, distribution or reproduction in other forums is permitted, provided the original author (s) or licensor are credited and that the original publication in this journal is cited, in accordance with accepted academic practice. No use, distribution or reproduction is permitted which does not comply with these terms. 